\title{
EXCHANGE OF INFORMATION AND EDUCATION IN COOPERATION BETWEEN AGRICULTURAL HOLDINGS MAINTAINING CONSERVATIVE BREED ANIMALS
}

\author{
Marta Domagalska-Grędys, $\mathrm{PhD}^{1}$ \\ Faculty of Agriculture and Economics, University of Agriculture in Krakow
}

\begin{abstract}
The development by means of cooperation, an exchange of knowledge and education is of crucial importance in the contemporary knowledge-based economy. The goal of the study was to determine important goals in cooperation with regard to the scope of knowledge and education of agricultural holdings maintaining conservative breed animals in the region of fragmented agriculture (South-Eastern Poland). The studied entities contribute to an increased biodiversity and maintenance of small agricultural holdings. The conditions of cooperation basing on an exchange of knowledge and education are laid down based on the results of a questionnaire study conducted among 145 agricultural holdings and principal component analyses (PCA). The evaluation of the exchange of knowledge and education varied within the industry. The highest degree of approval for the exchange of knowledge and education was among breeders of pigs and cows, the lowest among sheep breeders. It was demonstrated that participation in fairs and trainings improved the evaluation of analysed cooperation.
\end{abstract}

Keywords: cooperation goals, knowledge exchange and education, livestock conservative breeds, principal component analysis (PCA)

JEL codes: Q57, Q12, D71

\section{INTRODUCTION}

Development through cooperation in the exchange of knowledge and education is of crucial importance in the contemporary knowledge-based economy (Alee, 2003; Gloor, 2006; Castels, 2007; Dias and Franco, 2018). Cooperation between producers is valued by practitioners and theoretics even though, apart from the benefits (beneficial effects of scale and synergy), it may pose certain difficulties (conflicts, 'fare-dodging', increasing costs). The exchange determines the quality of functioning of contemporary society basing mainly on a network structure ${ }^{2}$ (Stępka and Subda, 2011).

Farmers who deal in animal production with conservative breeds obtain subsidies. However, their operations require knowledge and, often, also additional education (trainings). Complying with a number of procedures, combined with the specificity of production resulting from breeding of conservative breed animals, brings deficits in knowledge and skills to light and, therefore, translates into educational and

${ }^{1}$ Corresponding author: al. Mickiewicza 21, 31-120 Kraków, Poland, rrdomaga@cyf-kr.edu.pl, +4812 6624443

${ }^{2}$ Network social structure is a system of mutually-dependent objects forming an extensive and dynamic system. 
training needs of producers. Due to the fact that these farmers enter into relationships with research institutions, advisory centres and industry associations, they regularly cooperate and exchange knowledge with one another.

This paper discusses the problem of cooperation due to the exchange of information and knowledge and concentrates not on the effects of such an exchange, but on their evaluation among groups of breeders of respective species (cow, pig, sheep), farmer age, farm size and the period of introduction of conservative breeds. It has been observed that a high evaluation of cooperation goals regarding the exchange of knowledge and education of breeders are a symptom of desirable attitudes of producers and a premise for the development of agricultural holdings (a paradigm of a knowledge-based economy).

The purpose of the study was to indicate the conditions of cooperation in the scope of an exchange of information and education. Relationships were sought in which the evaluation of such cooperation was worst and would require intervention as well as those evaluated highly, certifying the presence of valuable social (intellectual) assets. Attention was drawn to the differences in the evaluation of knowledge and education due to qualities of various entities (farmer's education, work experience in the agricultural sector, period of introduction of conservative breeds and farm size).

\section{THEORETICAL BACKGROUND}

The functioning of economic entities depends on knowledge. The concept of a knowledge-based economy ${ }^{3}$ underlines the importance of the participation of various entities (organizations, natural persons and communities) in the processes of creation, assimilation, propagation and use of knowledge for the quick development of the economy and society. In macroeconomic terms, entities basing their operations on knowledge are considered to have a competitive advantage (Koźmiński, 2001; Wyrwicka, ed., 2011).

In developed countries, the increasing importance of cooperation of universities and public research in- stitutions with private economic entities and the scale of interdisciplinary projects leads to the invalidation of the traditional perception of the education system as the main creator of new knowledge (OECD, 2000). The European Union firmly emphasizes the development and continuous creation of new knowledge. Hence, the necessity of a priority approach to the research and development sector (R\&D) is increasingly more pronounced. In turn, the OECD pays particular attention to partnership-based cooperation between three segments of the agricultural knowledge and information system, i.e. research, education and advice and it recommends support in the articulation and solving of problems rather than, as it used to be, give ready solutions (Kania, 2014).

As follows from the results of Polish authors 'agricultural knowledge is often created without any link to the needs and expectations of its recipients (...), hence the effects of functioning of various research institutions and organizations are worse than could be expected, given the quality and quantity of existing intellectual assets' (Kania et al., 2011).

Cooperation among farmers and between farmers and institutions enables an exchange of knowledge, but there are certain prerequisites for cooperation: trust, easy communication, negotiations, cohesion (EIP-AGRI, 2016). The studies of agricultural producer groups conducted by Kiełbasa and Knapik (2018) reveal difficulties in knowledge management at the stage of transformation of concealed knowledge into common knowledge, as well as high costs of obtaining knowledge (expensive trainings and courses).

According to researchers, at present there is no well-functioning Agricultural Knowledge and Information System in Poland. Despite the existence of a majority of institutions and organizations specified therein, a lack of mutual and existing relationships prevents cooperation and functioning as a system (Kania et al., 2011). Therefore, it seems purposeful to commence efforts to create a farmer's knowledge network based on organizational networks (Alee, 2003; Franco, Mainardes and Martins, 2011; Pindado and Sánchez, 2017).

${ }^{3} \mathrm{KBE}$ - Knowledge-Based Economy. 


\section{COOPERATION OF BREEDERS IN THE CONTEXT OF KNOWLEDGE AND EDUCATION (THEORY)}

Thus far, the existing experience of breeders of conservative breed animals, in the scope of exchange of knowledge and education, has come down to several activities: participation in fairs, study tours and trainings. As a result, producers have gained knowledge and training and have entered into active cooperation, creating a specific knowledge network. These activities show a mechanism of repeatability (e.g. regular participation in fairs, exhibitions ${ }^{4}$ ) and participation (involvement) of institutions (agricultural advisory centres, industry associations) in the organization of study tours. It follows, from the opinion of farmers, that foreign tours were the main point of interest and were most effective in promoting cooperation and innovativeness. Solving market difficulties, creating new initiatives in industry associations abroad: in France, Germany, Italy (Tudisca et al., 2014) constituted a template of action for Polish breeders. In Poland, most industry associations are involved in the organization of study tours, hence this activity constitutes a traditional source of education and knowledge exchange.

In light of the aforementioned situation, it is reasonable to commence knowledge networking that should be preceded by an in-depth analysis of relationships between breeders of conservative breed animals and the surroundings: research institutions, industry associations, etc. (Aldrich and Cliff, 2003). In the case of the knowledge process, the primary entity is man who creates, collects, interprets and uses knowledge. In turn, the network perspective emphasizes social relationships, imposing researchers to analyse key processes supporting the creation of a learning 'formation' (internal communication, creation, accumulation and transfer of knowledge and innovation; Hajdukiewicz 2014). The results of studies concerning knowledge management (in the scope of Science and Technology - S\&T) at various stages of sustainable development show that an effective knowledge management system should include an institutional mechanism enabling communication and negotiations in network nodes. The authors underline that building an effective knowledge management system 'requires time and patience' (Cash et al., 2003; Hall, 2003; Meccheri and Pelloni, 2006; Rutten and Boekema, 2007).

\section{MATERIALS AND METHODS}

The test group comprised a population of 145 agricultural holdings representing agricultural holdings with animals of three conservative breeds (cattle, sheep and pigs) from South-Eastern Poland. The study concerned cooperation in the scope of inter-organizational relationships (farm-surroundings). The study concerned agricultural holdings that regularly cooperated with the most important entities in their surroundings ${ }^{5}$. For the purposes of this paper, a fragment of broader study of cooperation goals was used ${ }^{6}$. The study tool was a questionnaire from interviews conducted in 2017 among agricultural holdings. Analysis was conducted using the PCA method which enabled the reduction of numerous variables, relating to cooperation goals and helped in the determination of the importance of goals with regard to descriptive variables (age, farmer's work experience, farm size, year of introduction of conservative breeds). The separate cooperation area referred to as 3, namely, 'Exchange of knowledge and education' covered four cooperation goals with the highest correlation: exchange of strategic information, training, participation in fairs and study tours. Therefore, applying reference to a single dimension in the description of results: the exchange of information and education covered four cooperation goals simultaneously.

The adopted research method was intended to help in the understanding of various needs of recipients in

\footnotetext{
${ }^{4}$ National breeding exhibitions in Poznań, regional breeding exhibitions in Szepietowo.

${ }^{5}$ Research institutions, industry associations, agricultural advice centres, production means, suppliers and clients.

${ }^{6}$ By applying the PCA method, three areas of cooperation between breeders were identified: knowledge and education, marketing and market and development. This study focuses on knowledge and education referring to others in a contextual and justified situation for the better understanding of issues presented herein.
} 
the scope of knowledge and education, taking into account demographic changes (society gentrification) and experience of farmers (breeders of conservative breed animals).

\section{RESULTS AND DISCUSSION}

Conservative breed animal breeders and producers are currently at a stage of absorbing funds assigned to them for their contribution in maintaining biodiversity. Farmers are in a unique situation due to specificity of production, liaison with the niche market of products derived from such production and the obligation to comply with applicable rules (including but not limited to keeping breed books, reports). Market and legislative requirements drive the intensification of their actions related to seeking cooperation relationships, exchanging experience, knowledge and education. The authors' observations and interviews with breeders as well as representatives of industry institutions revealed difficulties in maintaining economic viability of agricultural holdings and 'if not for subsidies', would have abandoned their operations. The questionnaire interviews also revealed additional contexts of reference opinions. Breeders evaluated goals of cooperation differently, depending on the species they bred (cattle, pigs, sheep). What was also examined was whether other characteristics of agricultural holdings (size) and farmers (education, age) affected evaluation concerning cooperation in the scope of knowledge and education exchange.
The results of the reliability analysis for the cooperation dimension (scale) - exchange of information and education - is shown in Table 1 . The dimension should be considered reliable since Cronbach Alpha exceeds 0.7 (0.7587). Almost all items (cooperation goals) showed a strong correlation with the dimension: exchange of information and education (correlations above 0.5), hence they confirmed the correct selection of variables describing cooperation. The strongest correlations in the analysed dimension of cooperation (exchange of information) accompanied participation in fairs (0.6413) and trainings (0.5883; Table 1$)$. The highest diversity of evaluations concerned the exchange of strategic information (farmers evaluated this cooperation goal both high and low; standard deviation 3.9601; Table 1).

Analysis in the groups of agricultural holdings by animal species allows to conclude that the dimension of cooperation 3 , exchange of information was of highest importance in the creation of a cooperation network for cow and pig breeders and of least importance for sheep breeders (negative mean -0.3559 ; Table 2). Sheep breeders reported higher benefits of cooperation in the scope of the remaining goals: 1 - Development and 2 - Market.

The cooperation goals in the scope of exchange of knowledge and education were evaluated best by farmers with a secondary education (average score 0.1624; Table 3). The better the education, the lower the importance of cooperation dimension 3 concerning exchange of information and education. In turn,

Table 1. Results of reliability analysis for scale (main dimension) 'Information exchange and education'

\begin{tabular}{|l|c|c|c|c|c|}
\hline $\begin{array}{l}\text { Scale summary: mean 10.8000; standard deviation 4.81837; number of significant }(N) \text { 145; } \\
\text { Cronbach Alpha 0.758736; standardized Alpha 0.758583; mean correlation between items } 0.446052\end{array}$ \\
\hline $\begin{array}{l}\text { Cooperation goals of the dimension: } \\
\text { Exchange of information and education }\end{array}$ & Mean & Variance & $\begin{array}{c}\text { Standard } \\
\text { deviation }\end{array}$ & $\begin{array}{c}\text { Item and scale } \\
\text { correlation }\end{array}$ & $\begin{array}{c}\text { Cronbach } \\
\text { Alpha }\end{array}$ \\
\hline Exchange of strategic information & 8.00000 & 15.68276 & 3.96014 & 0.425192 & 0.76811 \\
\hline Trainings & 7.60000 & 14.48828 & 3.80634 & 0.588397 & 0.68777 \\
\hline Participation in fairs & 8.186207 & 12.8274 & 3.58153 & 0.641268 & 0.65291 \\
\hline Study tours & 8.613793 & 13.05085 & 3.61259 & 0.583195 & 0.68770 \\
\hline
\end{tabular}

Source: own research. 
Proceedings of the 2018 International Scientific Conference 'Economic Sciences for Agribusiness and Rural Economy' No 2, Warsaw, 7-8 June 2018, pp. 81-88

Table 2. Results of statistics of the cooperation dimension 'Exchange of information and education' between conservative breed species

\begin{tabular}{|l|c|c|c|}
\hline Specification & Means & Number of important cases & Standard deviation \\
\hline Cattle & 0.27961 & 52 & 0.96421 \\
\hline Breed & -0.35596 & 74 & 0.94251 \\
\hline Pig & 0.62112 & 19 & 0.78045 \\
\hline Total & 0.00000 & 145 & 1.00000 \\
\hline
\end{tabular}

Source: own research.

Table 3. Research results for the main dimension 'Exchange of information and education' of breeders according to the education of farmers

\begin{tabular}{|l|c|c|c|}
\hline Specification & Means & Number of important cases & Standard deviation \\
\hline Basic & -0.33158 & 14 & 0.87230 \\
\hline Vacation education & 0.08312 & 55 & 0.90751 \\
\hline Secondary education & 0.16242 & 51 & 1.12471 \\
\hline Higher education & -0.13584 & 13 & 0.96506 \\
\hline Other higher education & -0.64068 & 11 & 0.82640 \\
\hline Total & -0.00416 & 144 & 1.00222 \\
\hline
\end{tabular}

Source: own research.

the persons with primary education evaluated dimension 3 lower than average.

The trend of low evaluation of cooperation regarding the exchange of information and education in the oldest and youngest farms (more than 20 years) was clearly visible. Middle-aged farmers (aged 30-40) were more appreciative of information cooperation than younger and older producers (Table 4).
In conditions of fragmented agriculture in SouthEastern Poland, the study result indicating an interest in the exchange of knowledge and education of farms with a small farm size is important (Table 5). It should be noted that persons most interested in cooperation in the scope of exchange of knowledge and education were farmers owning mid-size farms with an area range of 15-30 ha. A point of concern is a lack of

Table 4. Research results for the main dimension 'Exchange information and education' of breeders according to farm age with animals of conservative breeds

\begin{tabular}{|l|c|c|c|}
\hline Specification & Means & Number of important cases & Standard deviation \\
\hline Up to 30 years old & -0.237486 & 16 & 0.982595 \\
\hline $30-40$ years old & 0.172187 & 31 & 1.090160 \\
\hline $41-50$ years old & 0.065770 & 39 & 0.963740 \\
\hline Above 50 years old & -0.081087 & 58 & 0.989759 \\
\hline Total & -0.004166 & 144 & 1.002227 \\
\hline
\end{tabular}

Source: own research. 
Proceedings of the 2018 International Scientific Conference 'Economic Sciences for Agribusiness and Rural Economy' No 2, Warsaw, 7-8 June 2018, pp. 81-88

Table 5. Results of statistics in the area of cooperation 'Exchange information and education' of breeders according to farm size with animals of conservative breeds

\begin{tabular}{|l|c|c|c|}
\hline Specification & Means & $\begin{array}{c}\text { Number of } \\
\text { important cases }\end{array}$ & $\begin{array}{c}\text { Standard } \\
\text { deviation }\end{array}$ \\
\hline Up to 5 ha & -0.401271 & 35 & 1.053216 \\
\hline $5-15$ ha & 0.097262 & 65 & 0.865632 \\
\hline $15-30$ ha & 0.161874 & 44 & 1.084404 \\
\hline Over 30 ha & -0.004166 & 144 & 1.002227 \\
\hline Total & -0.401271 & 35 & 1.053216 \\
\hline
\end{tabular}

Source: own research.

Table 6. Research results for the main dimension 'Exchange information and education' of breeders according to the time of introducing conservative breeds onto the animal farm

\begin{tabular}{|l|c|c|c|}
\hline Specification & Means & $\begin{array}{c}\text { Number of } \\
\text { important cases }\end{array}$ & $\begin{array}{c}\text { Standard } \\
\text { deviation }\end{array}$ \\
\hline Before 2004 & -0.041873 & 26 & 0.796098 \\
\hline Between 2005-2010 & 0.031021 & 63 & 1.120272 \\
\hline After 2010 & -0.000420 & 54 & 0.949647 \\
\hline Total & 0.005895 & 143 & 0.998425 \\
\hline
\end{tabular}

Source: own research.

recognition for cooperation in the scope of exchange of information and education among small, fragmented farms (up to $5 \mathrm{ha}$; average score: -0.4012).

The time of introduction of conservative breeds had a specifically differentiating impact on the evaluation of cooperation in the scope of exchange of knowledge and education. Farms with medium experience in maintaining conservative breeds of animals (introduced between 2005 and 2010) evaluated this dimension of cooperation higher than producers (breeders) with longer experience (more than 14 years) and shorter experience (approx. 7 years) (means, respectively: -0.0042 and -0.0418 ; Table 6 ).

\section{CONCLUSIONS}

The undertaken study and PCA allowed to determine the premises for creating knowledge by breeders and producers of conservative breed animals, making up for insufficient research in this regard. The studied phenomena determine needs in the scope of knowledge and education with regard to characteristics of farmers and their farms and provide certain legitimacy to estimate the knowledge which the study subjects may contribute to society. Referring to the important role of breeders in biodiversity processes, it may be concluded that the studied farmers, despite being in need of knowledge and education, regularly propagate knowledge by maintaining the tradition of breeding and meeting consumers on the market. Insight into the current situation of cattle, pig and sheep breeders helps in understanding the difference in their approach to knowledge and education. Those who highly value the exchange of knowledge (pig and cattle breeders) are able to gain more benefits from it thanks to their experience in tackling market cycles (pig market upward and downward trends) and good sector organization. In turn, Polish sheep breeders, by rebuilding their inventories (which saw a great reduction in the nineties), regained a competi- 
tive advantage not due to cooperation in the scope of exchange of knowledge and education, but thanks to opening to new (foreign) markets and the introduction of new products (lamb meat for export, traditional products, e.g. oscypek, bundz cheese varieties) as well as cooperation with national parks (access to EU funds). Individual knowledge was of lesser importance to them than collective knowledge (held by industry organizations and producer associations, e.g. 'Bacowie'). For sheep breeders, knowledge was obtained by industry organizations which made business contacts and used EU programme funding. In the view of sheep breeders, cooperation via associations was supposed to bring tangible market benefits (material benefits). Knowledge, as such, is not an interesting goal of cooperation. Enlarging farms may increase their interest in knowledge and education. In the current situation, the persons most interested in cooperation in the scope of exchange of knowledge and education were farmers owning midsize farms with an area range of 15-30 ha. A point of concern is a lack of recognition for cooperation in the scope of exchange of information and education among small, fragmented farms (up to $5 \mathrm{ha}$ ). A poor education of farmers reduces their motivation to gain knowledge and to educate themselves. The need to exchange knowledge and education is notoriously low in groups with the highest and lowest education. In the first group, the awareness of benefits from knowledge is low (precedence of experience over knowledge), while the second group has a low sense of losses due to insufficient knowledge (no need to learn anymore).

Short experience in maintaining conservative breeds of animals increases the need to exchange knowledge and educate among farmers. From the point of view of fragmented farms, cooperation is not an essential source of knowledge to stay on the market. It is also of significance that increased attendance during fairs and trainings improved overall evaluation in the scope of exchange of knowledge and education.

The strategy of producers not appreciating the need of cooperation based on an exchange of knowledge and education is a matter of concern. The role of research and advisory institutions is to fill this gap by partnership-based and 'tailor-made' education and training programmes. Industry organizations constitute a bridge in the transfer of knowledge, invaluable in the context of breeders' needs.

\section{Acknowledgements}

The publication concerns the BIOSTRATEG 2/297267/14/NCBR/2016 project, funded by the National Centre for Research and Development under the Biostrateg programme entitled 'Directions for the Use and Conservation of Livestock Genetic Resources in Conditions of Sustainable Development'.

\section{REFERENCES}

1. Aldrich, H.E., Cliff, J.E. (2003). The pervasive effects of family on entrepreneurship: toward a family embeddedness perspective. Journal of Business Venturing, 18 (5), pp. 573-596.

2. Alee, V. (2003). The Future of Knowledge. Increasing Prosperity Through Value Networks. Butterworth-Heinemann, Oxford.

3. Cash, D.W., Clark, W.C., Alcock, F., Dickson, N.M., Eckley, N., Guston, D.H., Jager, J., Mitchell, R.B. (2003). Knowledge systems for sustainable development. Proceedings of the National Academy of Sciences of the United States of America, 100 (14), pp. 8086-8091. https://doi.org/10.1073/pnas.1231332100

4. Castells, M. (2007). Społeczeństwo sieci [Network society]. Wydawnictwo Naukowe PWN, Warszawa.

5. Dias, C., Franco, M. (2018). Cooperation in tradition or tradition cooperation? Networks of agricultural enterpreneurs. Land Use Policy, 71, pp. 36-48.

6. EIP-AGRI (2016). Focus Group - New Entrants into Farming: Lessons to Foster Innovation and Entrepreneurship. European Comission. Final report - Resource document.

7. Franco, M.J.B., Mainardes, E., Martins, O. (2011). A review of inter-organizational networks: evidence from studies published in the period 2005-2008. Cuadernos de Administración. Organización Bogotá (Colombia), 24 (43), pp. 133-155.

8. Gloor, P.A. (2006). Swarm Creativity: Competitive Advantage through Collaborative Innovation Networks. Oxford University Press, Oxford.

9. Hajdukiewicz, A. (2014). European Union agri-food quality schemes for the protection and promotion of geographical indications and traditional specialities: an economic perspective. Folia Horticulturae, 26 (1), pp. 3-17. 
10. Hall, C.M. (2003). Wine and food tourism networks: a comparative study. In: Pavlovich, K., Akorrie, M. (eds.) Strategic Alliances and Collaborative Partnerships - A Case Book. Dunmore Press, Palmerston North, NZ, pp. 258-268.

11. Kania, J. (2014). System wiedzy i informacji rolniczej w rolnictwie polskim [The system of agricultural knowledge and information in Polish agriculture]. Prace Naukowe Uniwersytetu Ekonomicznego, 360, pp. 55-62 .

12. Kania, J., Drygas, M., Kutkowska, B., Kalinowski, J. (2011). System transferu wiedzy dla sektora rolno-spożywczego - oczekiwane kierunki rozwoju [Knowledge transfer system for the agri-food sector - expected directions of development]. Polish Journal of Agronomy, 7, pp. 22-28.

13. Kiełbasa, B., Knapik, W. (2017). Bariery i możliwości zarządzania wiedzą $\mathrm{w}$ grupach producentów rolnych w świetle własnych badań [Barriers and possibilities of knowledge management in groups of agricultural producers in the light of their own research[. Zeszyty Naukowe Politechniki Częstochowskiej. Zarządzanie, 26, s. 17-27.

14. Koźmiński, A.K. (2001). Jak stworzyć gospodarkę opartą na wiedzy [How to create a knowledge-based economy]. In: Strategie rozwoju Polski u progu XXI wieku [Poland's development strategies at the beginning of the 21 st century]. Kancelaria Prezydenta RP i Komitet Prognoz „Polska 2000 Plus”, PAN, Warszawa.
15. Meccheri, N., Pelloni, G. (2006). Rural entrepreneurs and institutional assistance: an empirical study from mountainous Italy. Entrepreneurship and Regional Development, 18 (5), pp. 371-392.

16. OECD (2000). Knowledge Management in the Learning Society. Paris.

17. Pindado, E., Sánchez, M., (2017). Researching the entrepreneurial behaviour of new and existing ventures in European agriculture. Small Business Economics, 49 (2), pp. 421-444.

18. Rutten, R., Boekema, F., (2007). Regional social capital: embeddedness, innovation networks and regional economic development. Technol. Forecasting Social Change, 74 (9), pp. 1834-1846.

19. Stępka, P., Subda K. (2009). Wykorzystanie analizy sieci społecznych (SNA) do budowy organizacji opartej na wiedzy [The use of social network analysis (SNA) to build a knowledge-based organization]. E-mentor, 1 (28), pp. 67-76.

20. Tudisca, S., Di Trapani, A.M., Sgroi, F., Testa, R., Giamporcaro, G. (2014). Role of alternative food networks in Sicilian farms. International Journal of Entrepreneurship Small Business, 22 (1), pp. 50-63.

21. Wyrwicka,M.K.(ed.)(2011). Sieci gospodarcze Wielkopolski - scenariusze transformacji wiedzy wspierającej innowacyjną gospodarkę Raport końcowy FORESIGHT [Wielkopolska economic networks-knowledge transformation scenarios supporting an innovative economy. Final report FORESIGHT]. Wydawnictwo Politechniki Poznańskiej, Poznań. 